\title{
Exclusion and bioethics: a Brazilian perspective
}

\author{
Exclusão e bioética: uma perspectiva brasileira
}

\begin{abstract}
This paper discusses exclusion from the perspective of a developing country, namely Brazil, associating semantic peculiarities to the behavior of different social groups and actors and relating them to the hierarchical structure that shapes society. Aiming to uncover these unconscious mechanisms, the article seeks to elicit individual reflection on the role that each person plays in the maintenance of the inequities inherent to social life in this context.
\end{abstract}

Key words Social inequity, Social discrimination, Power (psychology), Social hierarchy, Behavior
Resumo Este texto discute a exclusão da perspectiva de um país em desenvolvimento - Brasil - associando peculiaridades semânticas ao comportamento de diferentes grupos sociais e atores, relacionando-os à estrutura hierárquica que molda a sociedade. Buscando evidenciar esses mecanismos inconscientes o artigo procura estimular a reflexão individual sobre o papel social de cada um na manutenção das iniquidades inerentes à vida social neste contexto.

Palavras-chave Iniquidade social, Discriminação social, Poder (Psicologia), Hierarquia social, Comportamento
${ }^{1}$ Conselho Federal de Medicina. SGAS 915/lote 72, Asa Sul. 70390-150 Brasília DF Brasil.

doraporto@gmail.com 


\section{Exclusion and bioethics}

In Portuguese, the dictionarized meaning of exclusion ${ }^{1}$ characterizes the noun as an act that deprives or excludes someone from certain functions. The verb to exclude, i.e., the action of exclusion, admits the meanings of to put aside; depart; separate; deviate; not to admit; not to include; omit; deprive; despoil; send away; put out; remove; expel ${ }^{1}$. According to Schramm ${ }^{2}$, the use of the term social exclusion was first used by Lenoir to indicate groups of individuals and populations that were excluded from the development. In the contemporary world, it refers to the human condition of individuals and collectives that belong to societies in an increasing disruption of the social cohesion and, consequently, with an also increasing marginalization of people and social groups ${ }^{3}$.

Thus, it appears that the term exclusion is defined both by common sense and bioethics literature, indicating power inequities that materialize because of obstacles or real impediments to the access to social guarantees that distinguish the first, second and third generation of human rights. The appearance of the phenomenon is also identified when related to the historical processes that engendered the various facets of social exclusion. However, the reasons that determine the exclusion are not sufficiently specified in order to allow anyone to become aware of their role as an agent in the social reproduction of the phenomenon.

Therefore, this paper aims to stimulate the discussion of individual empowerment and its effects on the collective dimension, considering that the awareness about the reasons that shape moral judgments is the basis of any self process of social transformation. In this sense it is worth remembering the affirmation of Freire, which endorses the idea that, rather than by punishment, the adoption of ethically responsible behavior needs to be stimulated by the internalization of the need to know the ethical boundary between self and other: Freedom that does not do something because it fears the punishment is not being 'ethicalized'. The ethical need has to be accepted, so limits will become commitment and no more enforcement, it will be assumption. Punishment does not accomplish this. Punishment may create gentleness, silence. But the silenced do not change the world

\section{To exclude is to discriminate}

According to the Portuguese language dictionary, discrimination refers to the power of discriminating; distinguishing; it refers to discernment, which is also defined as an action or effect of separating, segregating, setting aside ${ }^{1}$. Its critical meaning in sociology indicates distinctions made in social life at the expense of certain groups that are deemed unacceptable by the majority for violating social norms and the principle of equality before the law $w^{5}$. The legal meaning of discrimination is the violation of the equality principle, as distinction, exclusion, restriction or preferences, motivated by race, color, sex, age, job, religion or political convictions ${ }^{5}$.

The dictionarized meanings of exclusion and discrimination allow us to detect a connection between these terms, considering the first as one of the possible consequences of the second. By inserting the human being as the "object" of exclusion in this equation, we find that the process is configured to eliminate or restrict the access to power by the other. The exclusion, therefore, applies to the one we consider different from us, being this us identified with the group that represents the hegemonic position in some context. But, would it be that simple? Would the exclusion return to any other or would there be some kind of specific "difference" that is able to provoke it?

Although you can observe throughout history that exclusion applies to different social divisions and groups, evidence shows that the factor that motivates it is not anchored in the mere perception of "difference". In many historical circumstances and several cultural contexts the difference is interpreted as a positive discrimination, catapulting the different to the realm of power or even putting it on a higher level, similar to that attributed to deity. This phenomenon happened in the process of the European "discovery" of the Americas, when the settlers took advantage, even in numerical minority, because of being identified as gods by the Amerindians. In contrast, the Spanish and Portuguese did not recognize the humanity of the natives and considered them animals, and therefore, they felt they had the right not only to expropriate their wealth, but mostly to take their lives without any pangs of conscience $e^{6,7}$.

Transposing this fact to the current days we may reaffirm the example of the use of the word "gringo" in Brazil, which according to the dictionary definition is a pejorative term that refers to the foreign individual, residing in or passing through the country ${ }^{8}$. However, no one would think of using this name for an immigrant or visitor from Bolivia, Paraguay, Peru or Africa, unless they had the physical characteristics associated 
with populations of the Northern Hemisphere, these being "gringos" in the most legitimate sense of the word, as used in the country. In other words, gringo identifies a foreigner we believe to come from a socio-cultural and economic reality that we consider superior to ours. Even being a pejorative term, indicating the recognition of the difference of the other, it does not apply to any other, only to the one (due to their place of origin) we believe to occupy a position superior to ours.

These examples indicate the crux of the matter related to the difference of the other; $a$ incapacidade em perceber a identidade humana dos outros, isto é, admiti-los, ao mesmo tempo, como iguais e como diferentes ${ }^{9}$. While we may find odd any "different", we tend to systematically exclude only the ones considered inferior". This implies that the phenomenon of exclusion registers, in the social structure, those who, for whatever reason (even arbitrary and random), are culturally defined as inferior to the others in a given social context.

\section{Who is different?}

The main identification parameter of exclusion and discrimination as a result of the difference, both for its antiquity and by its universality, is gender inequality. The differences between males and females among the higher primates seem to be reproduced in human societies, featuring the inequality of power and wealth between women and men throughout history, being, in itself, a form of violence against women: Violence against women is a manifestation of historically unequal power relations between men and women, which have led to domination over and discrimination against women by men and to the prevention of the full advancement of women'.

Studies of the social sciences point dimorphism as a determinant in this process, stressing the importance of factors such as physical strength, dominance and female subjugation by males ${ }^{10}$, but primarily pointing aspects related to reproduction and parental care as promoters of bipedalism and evolution ${ }^{11}$, which, millions of years later, eventually consolidated kinship structures $^{12}$ and, consequently, subordination positions of women in all societies on the plan$\mathrm{et}^{13-16}$. Even while avoiding getting in deep discussion about sex (biology) and gender (culture), which marked the feminist scientific production in the final decades of the twentieth century, it is important to mention that pregnancy and the subsequent parental care (including nursing), especially in social structures characterized by asymmetry between the sexes, to the detriment of women, was almost unanimously agreed by the various schools of thought, as a conditioning factor in their discrimination and exclusion throughout history.

It is also worth remembering that from the beginning of pregnancy until the primordium of consolidated teething of a child, allowing independent feeding, there is a period of approximately 33 months or nearly three years, in which women need to prioritize the care of baby in order to its survival. One can easily assume that this period, which is still characterized by the reduced physical autonomy of women (including limited mobility and reduced availability of time), must have greatly influenced the difficulty of female hominid groups to escape the domination of males. This process consolidated gender inequality throughout history, as cultures interpreted less autonomy and greater surviving difficulty of women (both in terms of physical force and as a result of procreation) as marks of inferiority. In other words, the differences between males and females became inequalities between men and women.

There is a second defining parameter of discrimination and exclusion that relates to the different, as old as the first one, which regards to the foreign, to the other different from us, which is applied to an individual or a social group. Paleontology has recorded hominid fossil with unequivocal marks of blows [that] confirm the occurrence of physical aggression episodes since the time of australopithecines, over a million years ago, until the modern age, worldwide ${ }^{17}$. Aggressiveness in higher primates, such as chimpanzees, was observed by Goodall who reports that the attacks are an expression of the hatred that is roused in the chimpanzees of one community by the sight of a member of another ${ }^{18}$. In other words, aggressiveness toward the other - as a domination and power strategy - can be detected between higher primates, including humans: Conflicts of interest between man and man are resolved, in principle, by the recourse to violence. It is the same in the animal kingdom, from which man cannot claim exclusion ${ }^{19}$.

Regarding the construction of the polarity between the us and the other among human individuals, Wrangham and Peterson report to surveys of Blake and Mouton, of the 1960s, who indicate that among us there exists the same process observed in chimpanzees: People quickly 
form groups, favor those in their own group, and are ready to be aggressive to outsider ${ }^{20}$. Wrangham and Peterson also claim that this process gives rise to all sorts of "isms" - racism, sexism and ethnocentrism, which are the basis of the exclusion and discrimination process of the oth$e r^{21}$. Regarding the construction of the identity of the $u s$, they refer to the statement of Sumner, reportet by same authors ${ }^{22}$ : This view of things in which one's own group is the center of everything [...] Each group nourishes its own pride and vanity, boasts itself superior, exalts its own divinities, and looks with contempt on outsiders ${ }^{23}$.

The reification of the differences based on the dichotomy between the us and the other ends by consolidating asymmetric power structures, commonly drawn by the idealization of the other as inferior: the apparent incapacity to constitute oneself as oneself without excluding the other - and the apparent inability to exclude the other without devaluing and, ultimately, hating $\mathrm{him}^{24}$. The estrangement of other, the inability of listening, the intolerance of differences and the growing hatred are harbingers of conflict - war - which has always moved the male portion of humanity towards the wish of power and wealth. Associated to virility, war is the most striking manifestation of discrimination and exclusion of the different. It is the signature of the alpha male in history and portrays their domination plans and their attempt to shape the social structure and mentality to achieve power and silence all who, according to their judgment, may threaten their position.

\section{Who are we?}

The assumption of the egalitarian morality from World War II, expressed by human rights treaties from different generations ${ }^{25-34}$, has led to changes in sensibility regarding the inequality between people and is manifesting itself in a more powerful way in the everyday forms of expression, which, in the last two decades, have increasingly been through a "filtering" process in order to eliminate words and terms considered politically "incorrect". Far from underestimating the effect on the language of this new sensibility, which should abolish or (at least) reduce inequalities identified in the speech ${ }^{35}$, I refer to a passage of Haraway in which the author identifies the problematic underlying the use of the terms "gender" and "race", bulwarks of academic research focused on the analysis and deconstruction of power relations in these two perspectives:
A curious linguistic point shows itself here: there is no marker to distinguish (biological) race and (cultural) race, as there is for (biological) sex and (cultural) gender, even though the nature/culture and biology/society binarisms pervade Western race discourse. The linguistic situation highlights the very recent and uneven entry of gender into the political, as opposed to the grammatical, lexicon. The non-naturalness of race - it is always and totally an arbitrary, cultural construction can be emphasized from the lack of a linguistic marker. [...] All these matters continue to hinge on unexamined functioning of the productionist, Aristotelian logic fundamental to so much Western discourse. In the linguistic, political, and historical matrix, matter and form, act and potency, raw material and achieved product play out their escalating dramas of production and appropriation. Here is where subjects and objects get born and endlessly reincarnated ${ }^{36}$.

This excerpt shows not only the difficulty of speaking and thinking about the world beyond the culturally pre-defined categories, but also points that, even in the dimension of language, for which we have greater conscious control, we face considerable difficulty when attempting to reframe the meaning of words that make up the world: words that define social roles and hierarchy that orders relations in the community. And if this difficulty is so clearly observable in the speech, what cannot be deduced about the action, which is primarily driven by emotion before reaching conscious reasoning? ${ }^{27,38}$ As Darwin observed, movements [...] reveal the thoughts and intentions of others more truly than do words, which may be falsified ${ }^{39,40}$. And, as Hall says, beyond verbal language, we constantly communicate our true feelings through behavior language $e^{40}$.

And it is precisely in the dimension of behavior that some cracks in the skin of this newfound egalitarian sensibility will more frequently appear; a sensibility that has been thickened in humanity for less than seven decades, since the promulgation of the Universal Declaration of Human Rights and other posterior statements ${ }^{25-34}$. It is in everyday life and especially in stress situations of everyday life that we transgress these new parameters of civility that were so harshly assimilated in this short period of time, considering the time of evolutionary change. When the $u s$ is placed at the top of the hierarchy we allow ourselves to vent our frustration uncontrollably, through the use of scurrility, which usually embodies our latent prejudices, in order to reaffirm our place in the social scale, our status, power and wealth. 
Inevitably, the us who presides over this conflict is identified with the hegemonic pattern, which translated to our Latinity would be the white, rich, successful, heterosexual and preferably good-looking man, although the latter is still optional in our society. The proximity or distance of this pattern gives legitimacy to each of us. It defines who will hear our admonition silently, who will respond to it, and also those that each of us fear to face openly, preferring to silence, even if resentfully. The conflict expresses our position in society, the right of speech which we believe to have and that is consolidated through the recognition from others.

However, currently we are able to observe that the factors that measure this proximity to the hegemonic standard are gradually ceasing to mirror traditional attributes in order to focus on the economic status and condition (power and wealth) that pervade and qualify the first (gender, race/ color, age). Angela Merkel, because of her origin and the position of her country in the ranking of nations, when walking through the pedestrian zone of the Atlantic Avenue, in Rio de Janeiro, would be considered to be more "gringo" and would be closer to the hegemonic pattern than Evo Morales, if walking through the same place.

Although this is an extremely occasional example, since it includes only a few women, it fully demonstrates that the ultimate ambitions of the social structure of the alpha males, power and wealth, can be transferred even to a woman, considering that she complies the social role prescribed for leadership. In contrast, other signs of exclusion - race, color and age - follow the traditional path, discriminating, segregating and excluding; which currently are also encouraged by the market that exposes the wounds of inequality. It is important to note that women who are not in the situation of Merkel (e.g., almost the entire female population of the planet) continue to be discriminated and excluded routinely, especially if they are black or indigenous, and specifically if they are poor.

The conflict can be easily observed in everyday social relations and becomes even more evident when circumstances bring to light instinctive behaviors. This is the case of traffic, which brings out all the prejudice, gestures and obscene words that, in general, reflect the inferiority we attach to individuals, groups and segments that are distant from the prescribed standard. If we think about it, the value of a curse is directly proportional to the ability to hurt the other by identifying them as someone considered culturally inferior. Nobody feels offended by being called beautiful, rich or intelligent, but, depending on the interlocutor and the situation, the use of the antonyms of these terms may hurt.

These and other examples, generously thrown on the streets in the heat of anger and under the influence of instincts, clearly demonstrate our prejudices. We describe mothers of the other as prostitutes, considering their inferiority by being women and having (presumably) a deviant sexual behavior in relation to the monogamous bourgeois morality. We insult men when we suggest they are homoaffective, in order to show their dissimilarity to the recommended standard. Therefore, in relation to all what we reject (and use as weapons to offend others because we consider them inferior), even without an examination of conscience, all that remains is to seriously examine our own morality, demonstrated in these bursts of anger, and deepen our perception of alterity in order to develop tolerance, common sense and harmony. Subsequently, allowing us to undertake the journey of mentality changing and the fullness of our humanity.

\section{Primate prima facie}

The empirical evidences we face in everyday life lead to conclude that we evolved little in our primate condition. We use cell phones, we fly, we access the internet, eat refined and sophistically prepared food and delude ourselves with our deeds, believing to be above the barbarism. However, our societies, based on the pyramidal structure of the alpha males, reproduce prejudice, discrimination and exclusion, emphasizing the blind competition that hinders any brotherly trait. Drawn on this instinctive substrate, the market stimulates consumption without limits, associating asset ownership with social status and consolidating a critical situation, bound to deplete our planet's resources.

In this difficult environment we allow ourselves to live as "there is no tomorrow", forgetting the past and the conquest achieved by the shedding of blood. Human rights, the greatest achievement in human consciousness that emerged during a century marked by two world wars, remain a distant dream for most of the world's population. And this gap becomes wider as we move away from the stereotype of the "predestined" to exercise power, being set up as abandonment to their own fate to those who hold to the edge of the social scale. We urge our helplessness against the harmful aspects of this 
reality and invoke the gods, the government or the market, begging them to rescue us. We ask them to take tough measures to move away the crowd of excluded that wander on earth.

If we believe that it is easier to assign someone the responsibility for our choices and actions (either the deity or men of power), we must remember that even in the Greco-Roman Pantheon (or in the Judeo-Christian Old Testament) the gods seem subject to instinctive bursts of anger, identically to the mortals. If we cannot completely rely on the grace of the emissaries of the supersensible sphere, let alone common sense of mankind, which seems to be in the pit of self-indulgent individualism. The greatest misfortune is to be subject to a sovereign whose goodness can never be assured and that always has the power to be bad when he wants to ${ }^{41}$.

Therefore, wouldn't it be prudent to bet the chips of existential transcendence on something we can control? Wouldn't it be wise to focus attention on ourselves and on the way we perceive the world in order to suppress - effectively - the behavior that legitimizes and justifies discrimination and exclusion of the other, the "different" that terrifies our imagination? I believe that besides being an individual choice, it is a clear choice for humanity: choosing humanity today is to opt for a project of self-restraint with regard to what we can do, of solidary sympathy against the suffering of people and of respect to the non-manageable dimension that the human being must keep to another human being. Voluntary restraint, solidarity, respect: to be human is not to accept a fact - biological or cultural - but to make a decision to undertake a journey ${ }^{42}$.

I think this is the proposal of bioethics, to point power imbalances and foster solutions for the conflicts and dilemmas arising from this inequity ${ }^{43}$. Through the changing of mentalities and the formation of an ethics awareness, applied to social life, it will be possible to reach the perception of equality and develop respect for the other, contemplating their intrinsic differences ${ }^{44}$. 
4. Freire P. Os silenciados não mudam o mundo. In: Freire AM, organizador. A pedagogia dos sonhos possíveis. São Paulo: Editora Unesp; 2001.

5. Birou A. Dicionário das ciências sociais. Lisboa: Publicações Dom Quixote; 1973.

6. Paulo III. Sublimus Dei. [Bula papal]. 2 jun. 1537. [cited 2013 Feb 18]. Available from: http://www.papalencyclicals.net/Paul03/p3subli.htm

7. Triana Escobar J. Bioética y exclusión persistente en América Latina y el Caribe: de la sociedad colonial a la sociedad tecnocientífica. Rev colomb. bioet. 2011; 6(1):178-185.

8. Todorov T. A Conquista da América: a questão do outro. São Paulo: Martins Fontes; 1983.

9. Organização das Nações Unidas (ONU). IV Conferência Mundial sobre a Mulher. Beijing/China; 1995. Rio de Janeiro: Fiocruz; 1996.

10. Wrangham R, Peterson D. Heranças. In: Wrangham R, Peterson D. O macho demoníaco. As origens da agressividade humana. Rio de Janeiro: Editora Objetiva; 1998. p. $224-225$.

11. Lovejoy CO. Evolution of human walking. Scientific American 1988; 82(9):118-125.

12. Lévi-Strauss C. As estruturas elementares do parentesco. $5^{\text {a }}$ edição. Petrópolis: Vozes; 2009.

13. Beauvoir S. O segundo sexo. São Paulo: Difusão Européia do Livro; 1960/1961.

14. Strathern M. The gender of the gift: problems with women and problems with society in Melanesia. Berkeley: University of California Press; 1988.

15. Rosaldo M, Lamphere L. Mulher, cultura e sociedade. Rio de Janeiro: Paz e Terra; 1979.

16. Gilligan C. A different voice. Cambridge: Harvard University Press; 1982.

17. Lessa A. Arqueologia da agressividade humana: a violência sob uma perspectiva paleoepidemiológica. Hist. cienc. saude-Manguinhos. 2004; 11(2):280-281.

18. Goodall J. A guerra. In: Goodall J. Uma janela para a vida. 30 anos com os chimpanzés da Tanzânia. Rio de Janeiro: Jorge Zahar Editor; 1991. p. 108.

19. Freud S. Por que a guerra? Carta a Einstein, 1932. In: Freud S. O mal-estar na civilização, novas conferências introdutórias à psicanálise e outros textos (1930-1936). São Paulo: Companhia das Letras; 2010. p. 419.

20. Blake RR, Mouton JS. The intergroup dynamics of win-lose conflict and problem-solving collaboration in union-management relations. In: Sherif M, editor. Intergroup relations an leadership: approaches an research in industrial, ethnic, cultural and political areas. Nova York: Wiley; 1962.

21. Wrangham R, Peterson D. Heranças. In: Wrangham R, Peterson D. O macho demoníaco. As origens da agressividade humana. Rio de Janeiro: Editora Objetiva; 1998. p. 241.

22. Wrangham R, Peterson D. O primata gentil. In: Wrangham R, Peterson D. O macho demoníaco. As origens da agressividade humana. Rio de Janeiro: Editora Objetiva; 1998. p. 356.

23. Sumner WG. Folkways. Boston: Ginn; 1906

24. Castoriadis C. O mundo fragmentado. As encruzilhadas do labirinto. Rio de Janeiro: Paz e Terra; 1992.

25. Organização das Nações Unidas (ONU). Declaração Universal dos Direitos Humanos. ONU; 1948. [cited 2013 Mar 2]. Available from: http://portal.mj.gov.br/ sedh/ct/legis_intern/ddh_bib_inter_universal.htm

26. Organização das Nações Unidas (ONU). Pacto de Direitos Econômicos, Sociais e Culturais (PIDESC). ONU; 1966. [cited 2013 Mar 2]. Available from: http://www. prr4.mpf.gov.br/pesquisaPauloLeivas/index.php?pagina $=$ PIDESC

27. Organização das Nações Unidas (ONU). Convenção Internacional sobre a Eliminação de Todas as Formas de Discriminação Racial (CIEFDR). ONU; 1968. [cited 2013 Mar 2]. Available from: http://www.pge.sp.gov. br/centrodeestudos/bibliotecavirtual/instrumentos/ discriraci.htm

28. Organização das Nações Unidas (ONU). Convenç̃o para Eliminação de Todas as Formas de Discriminação contra a Mulher (CEDAW). ONU; 1979. [cited 2013 Mar 2]. Available from: http://www.unifem.org. br/005/00502001.asp?ttCD_CHAVE=8466

29. Organização das Nações Unidas (ONU). Relatório da Conferência Internacional sobre População e Desenvolvimento. Cairo: ONU; 1994. [cited 2013 Mar 2]. Available from: http://www.direito.caop.mp.pr.gov.br/arquivos/ File/relatoriocairo.pdf

30. Organização das Nações Unidas (ONU). Plataforma de Ação da IV Conferência Mundial sobre a Mulher. Beijing; 1995. [cited 2013 Mar 2]. Available from: http://www. sepm.gov.br/Articulacao/articulacao-internacional/ relatorio-pequim.pdf

31. Organização das Nações Unidas (ONU). Declaração e Programa de Ação da Conferência Mundial sobre Desenvolvimento Social. Copenhagen; 1995. [cited 2013 Mar 2].Available from:http://www.direitoshumanos.usp.br/ index.php/Confer\%C3\%AAncias-de-C\%C3\%BApula -das-Na\%C3\%A7\%C3\%B5es-Unidas-sobre-Direitos -Humanos/declaracao-e-programa-de-acao-da-cupula-mundial-sobre-desenvolvimento-social.html

32. Organização das Nações Unidas (ONU). Declaração da Conferência do Milênio. ONU; 2000. [cited 2013 Mar 2]. Available from: http://bvsms.saude.gov.br/bvs/ publicacoes/declaracao_milenio_nacoes_unidas.pdf

33. Organização das Nações Unidas (ONU). Conferência Mundial contra o Racismo, Discriminação Racial, Xenofobia e Intolerância Correlata. Durban; 2001. [cited 2013 Mar 2]. Available from: http://www.unifem.org. br/sites/700/710/00001626.pdf

34. Organização das Nações Unidas para a educação, a ciência e a cultura (Unesco). Declaração Universal sobre Bioética e Direitos Humanos. Unesco; 2005. [cited 2013 Mar 2]. Available from: http://unesdoc.unesco.org/ images/0014/001461/146180por.pdf

35. Possenti S. A linguagem politicamente correta e a análise do discurso. Rev. Est Ling 1995; 4(2):125-142.

36. Haraway D. "Gênero" para um dicionário marxista: a política sexual de uma palavra. Cad. Pagu. 2004 JanJun; 22: 201-246. [cited 2013 Feb 19]. Available from: http://dx.doi.org/10.1590/S0104-83332004000100009

37. Damásio AR. O erro de Descartes. Emoção, razão e cérebro humano. São Paulo: Companhia das Letras; 1996. 
38. Lowen A. Pensar e sentir. In: Lowen A. Prazer. Uma abordagem criativa da vida. $5^{\text {a }}$ edição. São Paulo: Summus Editorial; 1984. p. 117-120.

39. Darwin C. A expressão das emoções no homem e nos animais. São Paulo: Companhia das Letras; 2000.

40. Hall ET. A linguagem silenciosa. Lisboa: Relógio D’água; 1994.

41. La Boétie E. Discurso da servidão voluntária. São Paulo: Brasiliense; 1999.

42. Savater F. Escolher a humanidade. In: Savater F. A importância da escolha. São Paulo: Editora Planeta do Brasil; 2004. p. 159.

43. Porto D, Garrafa V. A influência da Reforma Sanitária na construção das bioéticas brasileiras. Cien Saude Colet 2011; 16(Supl. 1):719-729.

44. Siqueira-Batista R, Schramm FR. A saúde entre a iniqüidade e a justiça: contribuições da igualdade complexa de Amartya Sen. Cien Saude Colet 2005; 10(1):129-142.

Artigo apresentado em 10/07/2014

Aprovado em 24/08/2014

Versão final apresentada em 26/08/2014 